\title{
A practical integrated radiomics model predicting intensive care hospitalization in COVID-19
}

\author{
Chiara Giraudo* (10, Giovanni Frattin, Giulia Fichera, Raffaella Motta and Roberto Stramare
}

It has been widely demonstrated that radiological imaging significantly contributes to diagnosing and monitoring pulmonary and systemic involvement of patients affected by COVID-19 using different techniques like chest X-ray (CXR), Computed Tomography (CT), and Magnetic Resonance Imaging [1-3]. Recently, several authors proposed the application of advanced imaging tools including machine learning and radiomics for COVID-19. For instance, Chandra et al. developed an automatic screening method based on radiomic features and Wang et al. used radiomics to distinguish COVID-19 from other viral infections $[4,5]$. Moreover, Ferreira Junior et al. [6], using a publicly available cohort, demonstrated that radiomics not only correlates with the etiologic agent of acute infections but also supports the short-term risk stratification of COVID-19 patients. Inspired by these interesting results, we developed and tested a CXR-based radiomics integrated model including demographics, first-line laboratory and clinical findings collected at admission and we assessed the predicting role of such model for Intensive Care Unit (ICU) hospitalization and overall outcome. We retrospectively examined CXR at admission of 203 patients hospitalized in our tertiary center for COVID19 (positive at RT-PCR) (Table 1). Eighteen patients deceased; 56 patients were treated in ICU and 147 in COVID-19 wards only. One radiologist with 10 years of experience in thoracic imaging, segmented the lungs of each patient as illustrated in Fig. 1 using an open source

*Correspondence: chiara.giraudo@unipd.it

Department of Medicine - DIMED, University of Padova, Via Giustiniani 2, 35100 Padua, Italy software (3D Slicer, www.slicer.org). The manual segmentation was performed by the segment editor and paint tools avoiding the inclusion of hilar and cardiac shadows. The radiomics extension was applied for the extraction of 33 features of first and second order: first-order statistics, gray level co-occurrence matrix, and gray level run length matrix. Factor analysis allowed the selection of five features highly correlating: maximum, kurtosis, inverse variance, cluster shade, and run length non-uniformity normalized (Fig. 1). The logistic regression analysis demonstrated that among the five radiomic features and the clinical and laboratory variables, only inverse variance, run length non-uniformity normalized, and C-reactive protein levels were significant predictors of ICU hospitalization (each, $p<0.05$ ). None of the examined variables played a significant role in predicting the overall outcome ( $p>0.05$, each).

To evaluate the robustness of the proposed method, a second reader, a medical student with 1 year of experience in diagnostic imaging repeated all segmentations and data extraction. The intraclass correlation coefficient analysis (two-way random effects, consistency, two raters) showed excellent results (each $>0.750$; Fig. 1) indicating that the technique is reproducible also by readers without a long-time expertise. Thus, our preliminary results demonstrate that a rapid model based on two radiomics feature and a basic inflammatory index, collected at admission, can predict ICU hospitalization. Our findings are partially in agreement with Ferreira Junior et al. [6] who showed that radiomics is a predictor not only of progression but also of the overall outcome. The difference regarding the outcome could be due to the low original author(s) and the source, provide a link to the Creative Commons licence, and indicate if changes were made. The images or other third party material in this article are included in the article's Creative Commons licence, unless indicated otherwise in a credit line to the material. If material is not included in the article's Creative Commons licence and your intended use is not permitted by statutory regulation or exceeds the permitted use, you will need to obtain permission directly from the copyright holder. To view a copy of this licence, visit http://creativecommons.org/licenses/by/4.0/. The Creative Commons Public Domain Dedication waiver (http://creativeco mmons.org/publicdomain/zero/1.0/) applies to the data made available in this article, unless otherwise stated in a credit line to the data. 
Table 1 Characteristics of the examined population

\begin{tabular}{llll}
\hline Characteristics at admission & Entire cohort & Patients treated in ICU & $\begin{array}{l}\text { Patients treated } \\
\text { in Covid-19 } \\
\text { wards }\end{array}$ \\
\hline Age (years) (mean \pm SD) & & $67.2 \pm 15.6$ \\
Gender (female/male) & $67.6 \pm 14$ & $68.8 \pm 10$ & $50 / 97$ \\
Fever (>37.5 C) (yes/no) & $60 / 143$ & $10 / 46$ & $127 / 20$ \\
Status (alive/deceased) & $178 / 25$ & $51 / 5$ & $136 / 11$ \\
Red blood cells count $\left(\times 10^{12} \mathrm{~L}^{-1}\right)($ mean $\pm \mathrm{SD})$ & $185 / 18$ & $49 / 7$ & $4.5 \pm 0.6$ \\
Hemoglobin $(\mathrm{g} / \mathrm{l})(\mathrm{mean} \pm \mathrm{SD})$ & $4.5 \pm 0.6$ & $4.4 \pm 0.5$ & $13 \pm 2$ \\
White blood cells count $\left(\times 10^{9} \mathrm{~L}^{-1}\right)($ mean $\pm \mathrm{SD})$ & $13 \pm 2$ & $8 \pm 4$ & $6.8 \pm 4$ \\
Lymphocytes count $\left(\times 10^{9} \mathrm{~L}^{-1}\right)(\mathrm{mean} \pm \mathrm{SD})$ & $7 \pm 4$ & $0.8 \pm 0.4$ & $1.1 \pm 1$ \\
C-reactive protein $\left(\mathrm{mg} / \mathrm{L}^{-1}\right)(\mathrm{mean} \pm \mathrm{SD})$ & $1.1 \pm 0.9$ & $116 \pm 88$ & $65 \pm 54$ \\
\hline
\end{tabular}

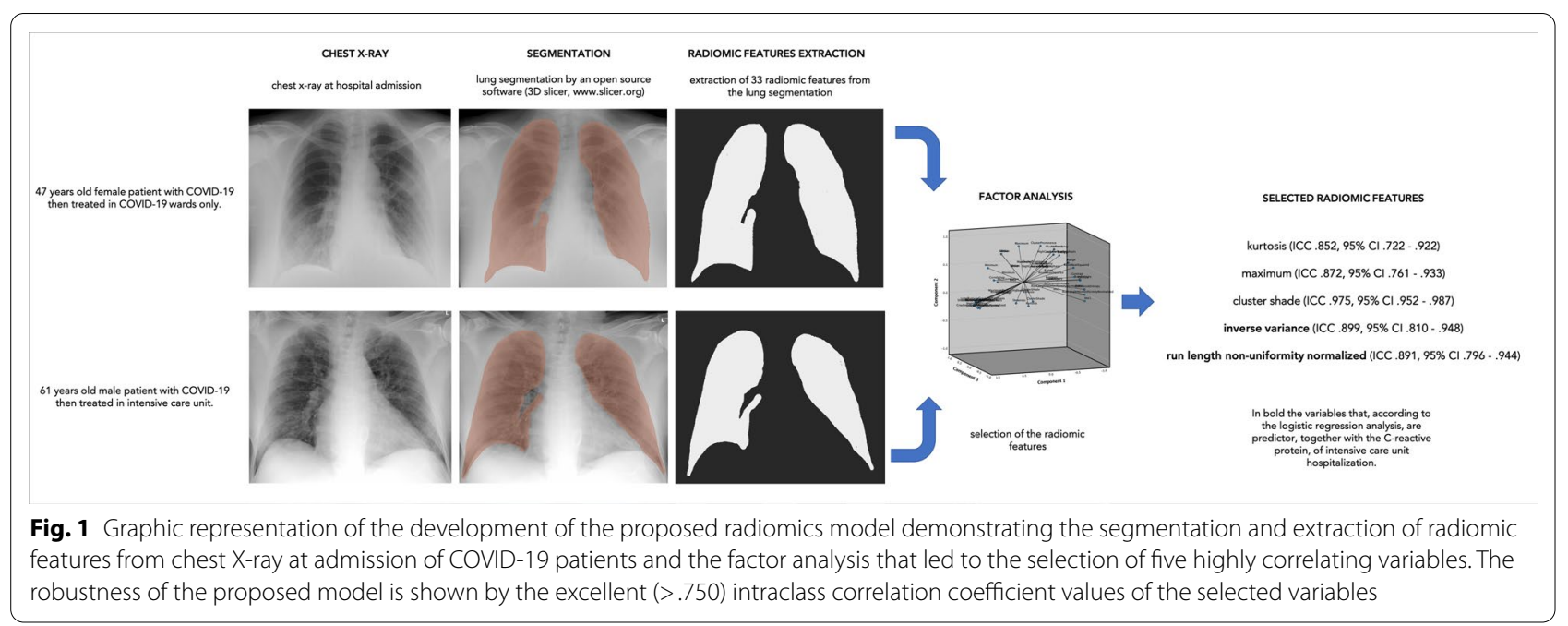

number of deceased patients in our cohort and the lower number of investigated features. A multicenter study with a more homogeneous distribution of the outcome may provide new insights. Regarding the number of features, we wanted to propose a practical radiomics model which could be placed side by side to routine reporting in clinical practice. It has to be addressed that several studies used CT for COVID-19 similar models since this technique is more accurate in characterizing disease severity and extension. Nevertheless, CXR still plays a dominant role especially as first approach and our results show that significant quantitative information can be extracted also from this diagnostic tool. Our study is limited by the retrospective study design. We call for future prospective research possibly correlating radiomics with semi-quantitative visual scores.

\section{Authors' contributions}

CG and RS designed the work; CG and GF analyzed the data; GF, GF and RM collected data; CG drafted the manuscript and interpreted the data; RM and
RS substantively revised the manuscript. All Authors read and approved the final manuscript.

Funding

There is no financial support to declare.

Availability of data and materials

The datasets used and/or analysed during the current study are available from the corresponding author on reasonable request.

\section{Declarations}

Ethics approval and consent to participate

Institution Review Board approval was obtained for this retrospective study.

\section{Consent for publication \\ Not applicable.}

\section{Competing interests}

The authors declare that they have no competing interests.

Received: 24 March 2021 Accepted: 1 April 2021

Published online: 14 April 2021 


\section{References}

1. Fichera G, Stramare R, De Conti G, Motta R, Giraudo C. It's not over until it's over: the chameleonic behavior of COVID-19 over a six-day period. Radiol Med. 2020;125:514-6.

2. Giraudo C, Fichera G, Motta R, Guarnieri G, Plebani M, et al. It's not just the lungs: COVID-19 and the misty mesentery sign. Quant Imaging Med Surg. 2021;11:2201-3.

3. Roy-Gash F, De Mesmay M, Devys JM, Vespignani H, Blanc R, Engrand N. COVID-19-associated acute cerebral venous thrombosis: clinical, CT, MRI and EEG features. Crit Care. 2020;24:419.

4. Chandra TB, Verma K, Singh BS, Jain D, Netam SS. Coronavirus disease (COVID-19) detection in Chest X-Ray images using majority voting based classifier ensemble. Expert Syst Appl. 2021;165:113909.

5. Wang L, Brendan K, Lee EH, Wang H, Zheng J, Zhang W, et al. Multi-classifier-based identification of COVID-19 from chest computed tomography using generalizable and interpretable radiomics features. Eur J Radiol. 2021;136:109552.

6. Ferreira Junior JR, Cardona Cardenas DA, Moreno RA, de Fatima de Sa Rebelo M, Krieger JE, Gutierrez MA. Novel chest radiographic biomarkers for COVID-19 using radiomic features associated with diagnostics and outcomes. J Digit Imaging. 2021. https://doi.org/10.1007/ s10278-021-00421-w.

\section{Publisher's Note}

Springer Nature remains neutral with regard to jurisdictional claims in published maps and institutional affiliations.
Ready to submit your research? Choose BMC and benefit from:

- fast, convenient online submission

- thorough peer review by experienced researchers in your field

- rapid publication on acceptance

- support for research data, including large and complex data types

- gold Open Access which fosters wider collaboration and increased citations

- maximum visibility for your research: over $100 \mathrm{M}$ website views per year

At BMC, research is always in progress.

Learn more biomedcentral.com/submissions 